UDC:658.5:330 131.7

DOI 10.35433/ISSN2410-3748-2020-1(26)-4

JEL Classification: G32, H12, M1

\author{
Dr Hanna Lewandowska, \\ Państwowa Uczelnia im. S. Batorego, \\ Skierniewice, Polska \\ Dr Olga Vikarczuk \\ Żytomierski Uniwersytet Państwowy \\ im. Iwana Franki, Ukraina \\ ORCID 0000-001-7574-5347
}

\title{
RYZYKO W ZARZĄDZANIU PRZEDSIĘBIORSTWEM
}

Ryzyko w zarządzaniu przedsiębiorstwem/organizacją może występować w każdym obszarze jej funkcjonowania. Zidentyfikowanie tych obszarów oraz występujacych odchyleń stanu rzeczywistego od planowanego może przyczynić się do zmniejszenia lub częściowego zniwelowania ryzyka. Przydatne do tego celu sa narzędzia w postaci wskaźników, które pozwalają na benchmarking kształtujących się wielkości. Pozwalają one również na wykrycie pojawiajacych się symptomów ryzyka upadłości.

Najszerzej i najczęściej wystęującym rodzajem ryzyka jest ryzyko organizacyjne. $W$ szerokim ujęciu wymaga ono identyfikacji obszarów zwiąanych z zarządzaniem zasobami

ludzkimi, kwestiami technicznymi oraz procesami organizacji i kontroli w ramach

organizacji. Ryzyko to definiuje sie jako ryzyko powstania strat wynikajacych $z$ niewłaściwego zorganizowania procesów wewnętrznych, ludzi i systemów lub ze zdarzeń zewnętrznych. Ryzyko organizacyjne zwiąane jest również z szybka innowacją w procesach świadczenia ustug, stosowanych technologii oraz ciagle zmieniajacych się nakładów $i$ kosztów. Ryzyko to można więc określić jako pochodna ryzyka strategicznego tj. błędnych założeń związanych z wdrożeniem działań prowadzacych do osiagnięcia założonego celu.

Ryzyko finansowe w organizacji stanowi wypadkowa wszystkich decyzji i działań podejmowanych przez zarządzających. Najczęściej sq to błędne zatożenia dotyczace wykorzystania zasobów organizacji przy planowaniu ustug. Zmienność otoczenia i jego oddziaływanie na organizacje wymaga jednak, aby w celu zapewnienia sobie dalszego rozwoju i przetrwania organizacje zwracały uwage na źródła i przyczyny powstawania ryzyka.

Przedstawione wyniki badań dwóch podmiotów gospodarczych funkcjonujacych w obszarze ochrony zdrowia pozwalaja na stwierdzenie, że z ryzykiem lepiej poradzi sobie podmiot for-profit niż podmiot non-profit.

Stowa kluczowe: ryzyko, controlling, organizacja, działalność for-profit, działalność non-profit, marketing, ekonomia menedżerska.

(C) Lewandowska Hanna, Olga Vikarczuk 


\section{RISK IN BUSINESS MANAGEMENT}

Risk might occur in any area or function of an enterprise / organization. Identifying those areas and possible deviations from the actual planned state plays a significant role in reducing or partially mitigating the risk. Different indicators have proven their effectiveness when it comes to benchmarking the observed values. They also allow the detection of emerging signs of bankruptcy risk.

The most common type of risk is organizational risk. Broadly speaking, it requires identification of areas related to human resources management, technical issues and control processes within the organization. This risk is defined as the risk of losses arising from improper organization of internal processes, people and systems, or from external events.

Organizational risk is also associated with rapid innovation in processes and services, applied technologies, and constantly changing inputs and costs. Therefore, this risk can be

defined as a derivative of strategic risk, i.e. incorrect assumptions related to the

implementation of actions leading to the achievement of the assumed goal.

Another prominent type of risk in the organization is financial risk. Financial risk is the result of all decisions and actions taken by managers. Most frequently it is related to incorrect assumptions about the use of organizational resources while planning services. However, changing environment and its impact on organizations requires those managers to pay attention to the sources and causes of risk in order to ensure survival and further development of the organization.

The presented results of the research conducted on two business entities operating in the health protection sector allow to assert that a for-profit entity will handle risk better than a non-profit entity.

Keywords: risk, controlling, organization, for-profit activities, non-profit activities, marketing, managerial economics.

Wprowadzenie. Gospodarki poszczególnych krajów są ze sobą ściśle powiązane i wzajemnie zależne. Jakieś wydarzenie lub jakaś zmiana w jednym kraju rozprzestrzenia się na inne. Powoduje to, że cały system meandrując w zupełnie nieprzewidywalnym kierunku ${ }^{1}$ zwiększa ryzyko dla funkcjonowania podmiotów gospodarczych bez względu na ich cel działania, tj. for- profit lub non-profit. Poprawne i skuteczne zarządzanie ryzykiem pozwala na osiągnięcie założonych celów i zaspokojenie wymagań interesariuszy (stakeholders). Stanowi również podstawę tworzenia ładu korporacyjnego (governance), tj. procesów i struktur dla uzyskania przepływu informacji w celu monitorowania działań nakierowanych na realizację celów organizacji ${ }^{2}$. Nowy okres charakteryzuje dążenie do obniżenia kosztów przy jednoczesnym zachowaniu lub podwyższeniu jakości produktów lub świadczonych usług. Ma to jednak

\footnotetext{
${ }^{1}$ P. Kotler, J. Caslione, Chaos. Zarzadzanie i marketing w erze turbulencji, MTBiznes, 2009, s. 21

${ }^{2}$ Zarządzanie ryzykiem w sektorze publicznym, Ministerstwo Finansów Warszawa, Projekt UE Transition Facility 2004/016- 829.01.08
}

(C) Lewandowska Hanna, Olga Vikarczuk 
związek ze zwiększonym ryzykiem i niepewnością dotykającą producentów i konsumentów. Występują one najczęściej obok siebie lub są ze sobą ściśle powiązane, ponieważ na ryzyko składa się zespół czynników, działań lub czynności powodujących nieprzewidziane straty mające wpływ na podmiot gospodarczy.

Celem opracowania jest przedstawienie zarządzania ryzykiem (finansowym) na przykładzie przedsiębiorstwa for-profit i przedsiębiorstwa nonprofit funkcjonujących $\mathrm{w}$ sektorze ochrony zdrowia. Przyjęto jednocześnie założenie, że każdy podmiot gospodarczy dąży do realizacji celów poprzez ekonomiczne i efektywne wykorzystanie posiadanych zasobów.

Przyjęte założenia oraz cel opracowania pozwoliły na sformułowanie hipotezy orzekającej, że: ryzyko finansowe prowadzonej działalności gospodarczej jest wyższe $\mathrm{W}$ przedsiębiorstwach non-profit niż w przedsiębiorstwach for-profit.

Metodologia. W celu weryfikacji hipotezy wykorzystano mierniki w postaci wskaźników określających kondycję badanych podmiotów gospodarczych. Wskaźnikami tymi są wskaźniki płynności finansowej oraz wskaźniki zadłużenia. Zestawienie otrzymanych wielkości pozwoliło na sformułowanie wniosków końcowych dotyczących ryzyka działalności tych podmiotów.

Ryzyko działalności gospodarczej. Ryzyko określane jest najczęściej jako ciąg działań prowadzących do braku osiągnięcia oczekiwanych korzyści i powstania szkody lub straty. A. Willet uważa, że ryzyko to zobiektywizowana niepewność związana z wystąpieniem niepożądanego zdarzenia ${ }^{3}$. F.H. Knight uważa natomiast, że ryzyko to niepewność mierzalna, która może mieć formę niemierzalną sensu stricto ${ }^{4}$. W.A. Rowe ${ }^{5}$ ryzyko zdefiniował jako negatywną

\footnotetext{
${ }^{3}$ A.H. Willet, The Economic Theory of Risk insurance, Philadelphia 1951, s.6

${ }^{4}$ F.H. Knight, Risk. Uncertainty and Profit, Chicago-London 1985, s. 233

${ }^{5}$ W.A. Rowe, Risk is potential for realisation of unwanted, negative consequences of an event [w:] An Anatomy of Risk, New York 1977, s. 24

(C) Lewandowska Hanna, Olga Vikarczuk
} 
konsekwencję zaistniałego zdarzenia, natomiast według R. Kendalla ${ }^{6}$ ryzyko to możliwość poniesienia straty. Ryzyko związane jest więc z przedsiębiorczością, która jest „procesem planowania, organizowania i prowadzenia działalności gospodarczej oraz przyjmowania związanego z nią ryzyka"7. Glosariusz Międzynarodowych Standardów Profesjonalnej Praktyki Audytu Wewnętrznego ryzyko definiuje w kategorii ,zaistnienia zdarzenia, które będzie miało wpływ na realizację założonych celów"8. J.M. Keynes i zwolennicy jego teorii rozróżniali niepewność i ryzyko. Uważali oni, że w przypadku niepewności zakres przyszłych zdarzeń nie jest znany i dlatego nie można określić prawdopodobieństwa jego wystąpienia, natomiast w przypadku ryzyka, zdarzenia podlegają przewidywalności i można zapisać je za pomocą formuł matematycznych ${ }^{9}$.

Ryzyko, jako zjawisko niejednorodne, może dotyczyć wszystkich dziedzin funkcjonowania przedsiębiorstwa, ponieważ występujące na pewnym poziomie powiązania (część organizacji lub komórki organizacyjne) powodują, że zmiana zachodząca $w$ jednym miejscu jest odczuwalna we wszystkich pozostałych ${ }^{10}$. Może to być ryzyko przewidywalne, które pozwala na zaplanowanie strat oraz ryzyko, którego czas, miejsce występowania i wielkość jest trudne do przewidzenia i skwantyfikowania.

Za najważniejsze czynniki ryzyka mające wpływ na funkcjonowanie przedsiębiorstwa należy uznać zmiany, które mają swoje źródło w samym przedsiębiorstwie (organizacji). Ryzyko to może wynikać m.in. ze złej polityki kadrowej, $\mathrm{z}$ nieodpowiednich decyzji menedżerskich oraz $\mathrm{z}$ zastosowania nieodpowiednich technologii. Ze względu na znaczenie ryzyka dla interesów przedsiębiorstwa można wyróżnić kilka obszarów jego występowania.

\footnotetext{
${ }^{6}$ R. Kendall, Zarzadzanie ryzykiem dla menedżerów, wyd. Liber Warszawa 1988, s. 15

${ }^{7}$ R.W. Griffin, Podstawy zarzadzania organizacjami, PWN Warszawa 2005, s. 311

${ }^{8}$ Glosariusz Międzynarodowych Standardów Profesjonalnej Praktyki Audytu, The Institute of Internal Auditors, Altamonte Springs, Floryda 2001

${ }^{9}$ U. Basseler, J. Heinrich, W. Koch, Grundlagen und Probleme der Volkswirtschaft, Wirtschaftsverlag Bachem, Koln 1991, s. 344

${ }^{10}$ P. Kotler, J. Caslione, Chaos. Zarzadzanie i marketing w erze turbulencji, MTBiznes, 2009, s. 29

(C) Lewandowska Hanna, Olga Vikarczuk
} 
Pierwszym $\mathrm{z}$ nich jest ryzyko dotyczące zasobów majątkowych, które dodatkowo można podzielić na ryzyko dotyczące wartości rzeczowych (np. awarie urządzeń), finansowych (zwłoka w spłacie należności, ogólny kryzys finansowy). Drugim obszarem jest ryzyko odpowiedzialności, które dotyczy m.in. obszarów księgowości, organizacji gospodarowania odpadami. Trzecim obszarem jest ryzyko dotyczące ludzi, które realizuje się wraz z występowaniem wypadków przy pracy, strajków, zmian przepisów pracowniczych, itp. ${ }^{11}$

Najszerzej i najczęściej występującym rodzajem ryzyka jest ryzyko organizacyjne. W szerokim ujęciu wymaga ono identyfikacji obszarów związanych z zarządzaniem zasobami ludzkimi, kwestiami technicznymi oraz procesami organizacji i kontroli w ramach organizacji. Ryzyko to definiuje się jako ryzyko powstania strat wynikających $\mathrm{z}$ niewłaściwego zorganizowania procesów wewnętrznych, ludzi i systemów lub ze zdarzeń zewnętrznych. Ryzyko organizacyjne związane jest również z szybką innowacją w procesach świadczenia usług, stosowanych technologii oraz ciągle zmieniających się nakładów i kosztów. Obejmuje również wadliwą strukturę organizacyjną tj. m.in. brak wyraźnego rozgraniczenia funkcji i zakresu odpowiedzialności pracowników. Do źródeł ryzyka organizacyjnego można także zaliczyć nieodpowiednie kwalifikacje menedżerów i pracowników zajmujących określone stanowiska oraz brak odpowiedniej infrastruktury. Ryzyko to można więc określić jako pochodną ryzyka strategicznego tj. błędnych założeń związanych z wdrożeniem działań prowadzących do osiągnięcia założonego celu. Najbardziej znanym ryzykiem jest ryzyko ekonomiczne. Może ono być określane w kontekście prowadzonej działalności gospodarczej, tj. dążeniu organizacji do uzyskania założonych celów oraz możliwości ich osiągnięcia. Celami tymi w ujęciu ekonomicznym mogą być: wypracowanie określonego zysku, wysokość obrotów, realizacja strategii organizacji i procesu

\footnotetext{
$11 \mathrm{~W}$. Ronka-Chmielowiec, Wykorzystanie ubezpieczeń do zarzadzania ryzykiem w przedsiębiorstwie [w:] Zarządzanie ryzykiem działalności organizacji, C.H. Beck Warszawa 2010, s.52
}

(C) Lewandowska Hanna, Olga Vikarczuk 
innowacyjnego, etc. Ryzyko towarzyszy więc organizacji w ustalaniu celów i poszukiwaniu metod i narzędzi prowadzących do tego celu. Badania nad rodzajem występującego ryzyka powinny umożliwić menedżerom ograniczenie błędnych decyzji prowadzących do ponoszenia strat lub rozbieżności $\mathrm{z}$ wyznaczonymi celami.

Można dokonać podziału ryzyka od strony:

- $\quad$ przyczyny występowania zdarzeń krytycznych,

- mechanizmu realizowania się tych zdarzeń,

- $\quad$ skutków występujących zdarzeń.

Ryzyko można sklasyfikować na trzech poziomach: poziom najwyższy obejmuje ryzyko nieakceptowalne, poziom średni polega na analizowaniu kosztów i korzyści (ryzyko akceptowalne) oraz poziom najniższy (ryzyko nieistotne) identyfikujący ryzyko, którym można się nie zajmować.

Działania związane $\mathrm{z}$ ryzykiem pozwalają na jego zidentyfikowanie, analizowanie, oszacowanie i wpływanie na jego poziom. Może to odbywać się na poziomie procesów decydujących o realizacji celów organizacji, zjawisk zakłócających działalność oraz zasobów ludzkich. Ryzyko stanowi więc integralną część procesu planowania, kierowania i raportowania. Istotne jest więc zarządzanie ryzykiem, które jako proces obejmuje etapy, fazy i metody. Pozwala to na jego zdefiniowanie jako zagrożenia dla osób, rzeczy i interesów organizacji $\mathrm{w}$ ramach prowadzonej działalności i istniejących powiązań $\mathrm{z}$ otoczeniem.

Identyfikacja ryzyka powinna uwzględniać przyczyny zewnętrzne i wewnętrzne, ponieważ mają one wpływ na podejmowanie decyzji zarządczych. Następnie należy dokonać analizy przyczyn, które wywołują określone ryzyko, ich sprzężenie zwrotne oraz możliwość wystąpienia zdarzeń wyzwalających nowe ryzyka. Ponadto należy ustalić, czy organizacja ma wpływ na przyczyny ryzyka i możliwość ich usunięcia lub wyeliminowania. W analizie relacji przyczynowo - skutkowych istotne jest określenie prawdopodobieństwa (C) Lewandowska Hanna, Olga Vikarczuk 
wystąpienia w przyszłości zdarzeń wyzwalających ryzyko. Jednym z narzędzi tej identyfikacji może być analiza SWOT, tj. ocena słabych i mocnych stron organizacji oraz analiza otoczenia. Celem natomiast tej identyfikacji jest relatywnie wczesne stwierdzenie występujących zagrożeń dla działalności przedsiębiorstwa/organizacji, do których należą m.in. nieprawidłowości w sprawozdaniach finansowych, wielkość zysku lub straty, zmiana wymagań odbiorców, etc.

Radzenie sobie z ryzykiem w organizacji wymaga wysokiej elastyczności w jej zdolności dostosowania się do zmiennych warunków rozwoju. Jednym ze sposobów ograniczania ryzyka jest odpowiednie przetwarzanie pozyskanych informacji o problemach organizacji i zmianach w jej otoczeniu.

Właściwa ocena ryzyka może zapobiec powstawaniu w przyszłości szkody i strat ${ }^{12}$. Do tego celu nadają się metody prognozowania, które służą przewidywaniu możliwych skutków obecnych działań w przyszłości ${ }^{13}$. Obejmują one badanie przyczyn, które miały wpływ na powstanie lub zaistnienie ryzyka. Narzędziami wykorzystywanymi do określenia ryzyka może być analiza i prognoza rozwoju organizacji oraz zmian w jej otoczeniu.

Zarządzanie różnymi rodzajami ryzyka występującymi w organizacji powinno pozwolić na utrzymanie kosztów na racjonalnym poziomie oraz prowadzić do stabilizacji finansowej. Powinno również odpowiedzieć na pytanie, w jaki sposób aktualny potencjał przedsiębiorstwa może wpłynąć na jego rozwój i wyniki w przyszłości.

Dla celów porównawczych występującego ryzyka najbardziej odpowiednia jest analiza wskaźnikowa, która dostarcza informacji o sytuacji finansowej organizacji. Stosowane wskaźniki umożliwiają nie tylko dokonanie oceny działalności organizacji, ale również umożliwiają ocenę ryzyka oraz formułowanie wniosków na przyszłość. Unifikacja wskaźników powoduje

\footnotetext{
12 T.T. Kaczmarek, Zarzadzanie ryzykiem, Difin 2010, s.132

13 S.G. Marks, Samuelson W.F., Ekonomia menedżerska, PWE 1998, s. 400

(C) Lewandowska Hanna, Olga Vikarczuk
} 
również, że analiza wskaźnikowa pozwala porównać działalność organizacji z innymi organizacjami (benchmarking). Największą rolę odgrywa jednak analiza porównawcza i analiza trendu. Analiza porównawcza pozwala na wyliczenie wskaźników na podstawie sprawozdań finansowych i porównanie ich z wartością wskaźników uzyskanych przez organizacje z tej samej branży, natomiast analiza trendu pozwala na porównanie wartości wskaźników uzyskiwanych w kolejnych okresach przez badany podmiot. Najczęściej stosowanymi wskaźnikami są: wskaźniki płynności finansowej, rentowności, zadłużenia i efektywności wykorzystania aktywów.

Niezwykle pomocnym narzędziem w ustalaniu ryzyka działalności przedsiębiorstwa/organizacji $\mathrm{W}$ oparciu o dostępne dane jest proces symulowania sytuacji finansowej za pomocą odpowiedniego oprogramowania aplikacyjnego. Pozwala to na wyznaczenie zależności między zmiennymi decyzyjnymi i pozycjami wyjściowymi na podstawie danych empirycznych, prognozowaniu przyszłych wartości wyznaczonych zmiennych decyzyjnych oraz modelowaniu poszczególnych pozycji rachunku zysków i strat i pozycji bilansu. Sporządzenie takiej prognozy pozwala w wielu przypadkach nie tylko na uniknięcie ryzyka, ale również odpowiada na pytanie „co się stanie, jeśli?”.

Controlling jako instrument zarządzania ryzykiem. Controlling jako jedna $\mathrm{z}$ koncepcji zarządzania przedsiębiorstwem nakierowana jest na wspomaganie procesu planowania, kierowania i kontroli. Wspomaga $\mathrm{w}$ ten sposób adaptację i koordynację działalności przedsiębiorstwa. Jednym z wielu jego celów jest dostarczanie danych o wszystkich aspektach działalności podmiotu i jego otoczeniu, konstruowanie wskaźników i miar oceny finansowej oraz przygotowaniu informacji bieżących i strategicznych w taki sposób, aby menedżerowie mogli nie tylko porównywać rzeczywistość $\mathrm{z}$ planem, ale również podejmować niezbędne decyzje wykonawcze. Controlling wspomagając procesy zarządzania pozwala na identyfikację ryzyka, jego analizę i ocenę stopnia tego ryzyka (nieakceptowalne, akceptowalne, nieistotne). 
Działania te pozwalają również na ustalenie wzajemnych powiazań uwzględniających cele przedsiębiorstwa, jego strategię i plany. Bieżące informacje pozwalają również na podejmowanie odpowiednich działań zapobiegawczych lub naprawczych.

Controlling odnoszący się do ryzyka powinien odpowiadać na następujące pytania $^{14}$ :

- jakie należy przyjąć metody zarządzania,

- $\quad$ jakie narzędzia będą najbardziej użyteczne,

- jak połączyć informacje o ryzyku z poszczególnych działów przedsiębiorstwa i najbliższego otoczenia,

- $\quad$ w jaki sposób monitorować poziom ryzyka i jak doprowadzić do jego kompensacji,

- $\quad$ w jaki sposób sprawować bieżąca kontrolę nad skutecznością podjętych działań wobec zidentyfikowanego ryzyka,

- $\quad$ za pomocą jakich metod i narzędzi rozbudować wewnętrzny system raportowania

oraz

- jak szkolić pracowników w zakresie umiejętności wykrywania zagrożeń/ryzyka.

Odpowiedzi na pytania można znaleźć wyodrębniając w przedsiębiorstwie/organizacji obszary odpowiedzialności. Mogą nimi być zakład, oddział, wydział, komórka lub każda inna struktura przedsiębiorstwa/organizacji, której przypisano odpowiedzialność za wykonywane czynności/zadania. Nie bez znaczenia w controllingu ryzyka są również kontrole zachowań pracowników. Pracownicy stanowiący najważniejsze aktywa każdego przedsiębiorstwa/organizacji mają wpływ na jego wydajność i efektywność (wynik finansowy). Popełniane przez nich błędy

${ }^{14}$ T.T. Kaczmarek, Zarządzanie ryzykiem, Difin 2010, s.132

(C) Lewandowska Hanna, Olga Vikarczuk 
są najczęstszym źródłem powstającego ryzyka wynikającego $\mathrm{z}$ braku odpowiednich kompetencji lub odpowiedzialności.

Dla oceny ryzyka istotny jest szybki i pełny przepływ informacji w wariancie równoległym (między komórkami) i kaskadowym (między kierownictwem a pracownikami). Brak takich działań prowadzi do popełniania błędów przez zarządzających. Celowi temu mogą służyć kontrole jako narzędzia umożliwiające dokonanie korekty lub modyfikacji bieżącego procesu planowania. Poprawnie przeprowadzone pozwalają określić różnice, które występują między wielkościami planowanymi i osiąganymi. Mogą więc dotyczyć uzyskanych wyników, opracowanych prognoz, nadzoru, zachowań pracowników, itp.

Kontrole pozwalają ustalić, jakie rodzaje ryzyka i w jakim stopniu negatywnie wpłynęły na realizowany cel. Powinny jednak dotyczyć nie tylko obszarów, w których wystąpiły straty, ale również tych generujących zyski. Brak pojawienia się ryzyka wymaga również ustalenia przyczyn, ponieważ może mieć to wpływ na dalsze zarządzanie przedsiębiorstwem. Sformułowanie wniosków wynikających z przeprowadzonych ex post kontroli pozwala na zbudowanie optymalnego scenariusza gwarantującego dalszy rozwój przedsiębiorstwa.

W ocenie ryzyka istotne znaczenie należy przypisać tzw. systemowi wczesnego ostrzegania. Jego celem, na podstawie obserwacji i analizy otrzymanych wskaźników, jest wychwycenie wszelkich informacji o zmianach dokonujących się w przedsiębiorstwie i jego najbliższym otoczeniu. Pozwali to na identyfikację mającego pojawić się ryzyka i wcześniejsze zareagowanie oraz wyeliminowanie lub spłycenie tego zagrożenia.

Pojawiająca się, nawet niewielka różnica, pomiędzy wielkościami planowanymi a osiąganymi jest pierwszym symptomem mogącego pojawić się ryzyka w każdym obszarze działalności przedsiębiorstwa. Kontrolę tych 
odchyleń można przeprowadzić etapowo poczynając od analizy ogólnej i przechodząc kolejno do analizy szczegółowej.

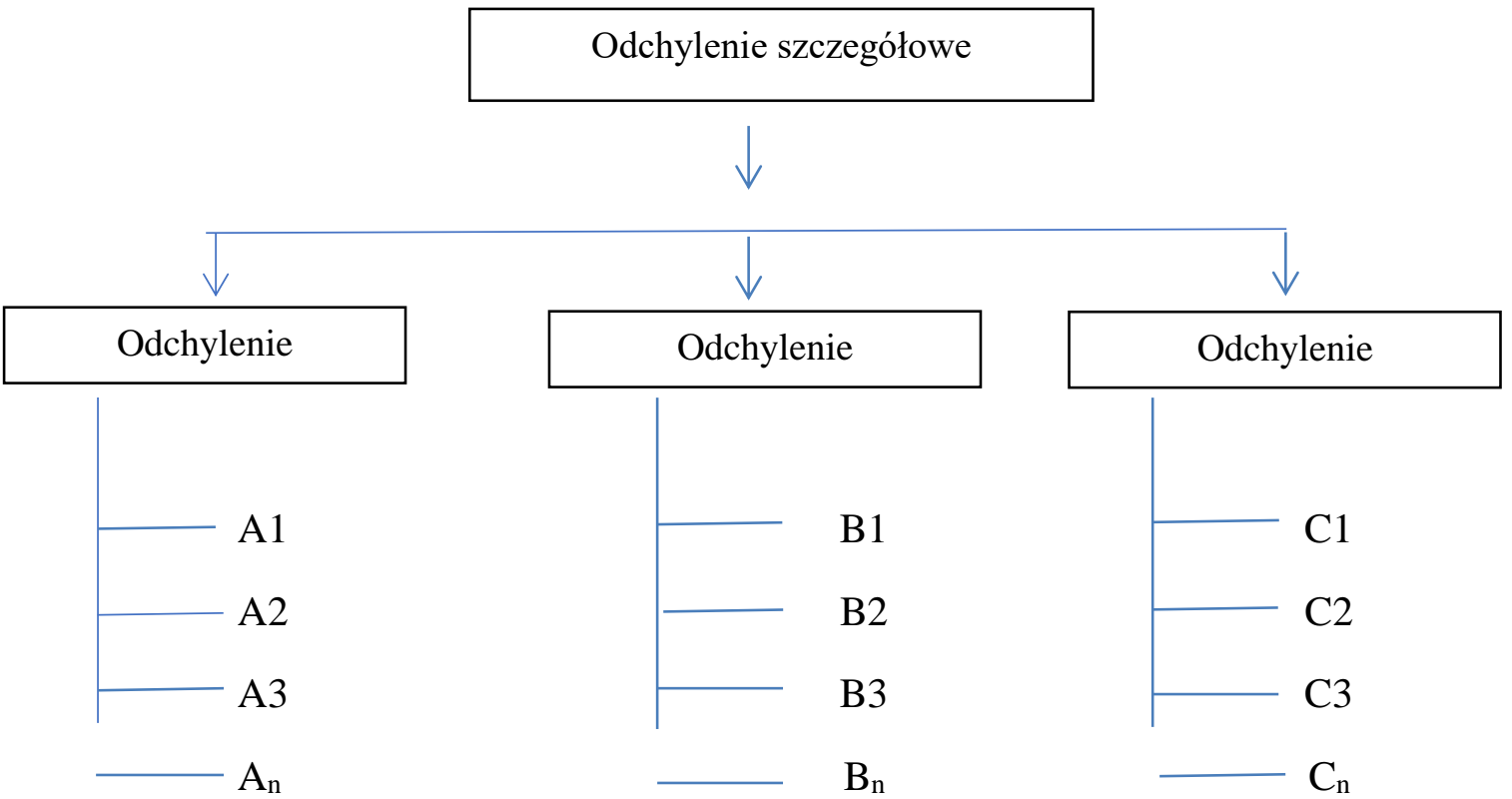

Źródło: opracowanie własne na podstawie: R.S. Kaplan, Advanced Management Accounting, PrenticeHall, New Jersey 1982, s. 307

Schemat 1. Kontrola odchyleń

Możliwe jest również określenie i porównanie różnicy pomiędzy odchyleniami szczegółowymi. Sposób postępowania w głównej mierze zależy od przyjętej przez decydentów polityki zarządzania przedsiębiorstwem/organizacją. Działania te, podjęte w odpowiednim czasie i miejscu, pozwalają również na zmniejszenie kosztów tych działań (tabela 1).

Tabela 1.

Działania i koszty obszarów ryzyka

\begin{tabular}{|c|c|}
\hline Działania & Koszty \\
\hline $\begin{array}{l}- \\
\text { - } \\
\text { przepływiększenie zasobu }\end{array}$ & $\begin{array}{llll} & \text { podwyższenie jakości towarów i } \\
\text { usług } & & & \end{array}$ \\
\hline - $\quad$ lepsze planowanie działalności & - $\quad$ kontrola jakości \\
\hline $\begin{array}{lrrr}- & \text { dobór } & \text { odpowiednich narzędzi do } \\
\text { oceny ryzyka } & & & \\
\end{array}$ & pozyskiwanie informacji z rynku \\
\hline $\begin{array}{ll}- & \text { eliminowanie przyczyn ryzyka }\end{array}$ & podział ryzyka z dostawcami \\
\hline usuwanie przyczyn ryzyka & $\begin{array}{lcc}\text { - brak } & \text { realizacji } & \text { podpisanych } \\
\text { kontraktów (kary, odsetki itp.) } & \end{array}$ \\
\hline 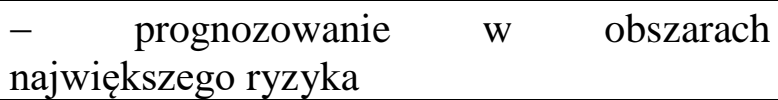 & - $\quad$ utrata dostawców \\
\hline
\end{tabular}

Źródło: opracowanie własne na podstawie: T.T. Kaczmarek, Zarządzanie ryzykiem, Difin 2010, s. 160 
Brak działań zapobiegawczych może skutkować upadkiem przedsiębiorstwa/organizacji. Pojawiające się symptomy powiązane są ściśle:

- $\quad$ ze strukturą organizacyjną,

- $\quad$ zarządzaniem zasobami ludzkimi,

- finansami.

W pierwszym przypadku symptomami zagrożenia mogą być: zbyt zbiurokratyzowana struktura hamująca szybki przepływ informacji, długi czas jaki upływa od podjęcia decyzji do jej wprowadzenia, łamanie przyjętych zasad i procedur, podejmowanie drugorzędnych decyzji na najwyższym szczeblu kierowniczym, braki możliwości awansu poziomego i pionowego, thumienie oddolnych inicjatyw pracowniczych, rozbudowane uprawnienia związków zawodowych, dla których istniejący status quo jest najbardziej akceptowalny itp. W obszarze zarządzania zasobami ludzkimi czynnikami prowadzącymi do ryzyka upadłości mogą być: brak jasno określonych i przypisanych obowiązków, brak informacji o zadaniach wykonywanych równolegle przez inne działy/komórki, brak odpowiednich kompetencji, frustracja pracowników, brak przypisania zadań do konkretnych pracowników, rozmyta odpowiedzialność za powierzone zadania, nieoczekiwane odejścia pracowników, brak dobrej atmosfery pracy, brak polityki zatrudnienia, itp. Symptomami finansowymi prowadzącymi do powstania ryzyka upadłości są natomiast: pogarszające się wskaźniki płynności finansowej, wzrastające wskaźniki zadłużenia i rotacji należności, pogarszające się wskaźniki wydajności pracy oraz nieuzasadnione cięcia kosztów itp.

Ocena ryzyka finansowego. Case study. Odzwierciedleniem decyzji podejmowanych przez zarządzających (interesariuszy) w każdej organizacji jest wynik finansowy. Jego wartość pozwala na ocenę ryzyka związanego z przyjętym modelem zarządzania organizacją oraz podjęcie działań modyfikujących przyjętą strategię. Stanowi również sygnał dla właścicieli udziałowców o zdolności organizacji do rozwoju lub przetrwania.

(C) Lewandowska Hanna, Olga Vikarczuk 
Analiza ryzyka w niniejszym opracowaniu przeprowadzona zostanie dla dwóch organizacji funkcjonujących w sektorze ochrony zdrowia. Pierwszy $\mathrm{z}$ badanych podmiotów (,X”) jest organizacją for-profit (prywatną kliniką wielospecjalistyczną). Jako spółka prawa handlowego funkcjonuje od 2012 roku i zatrudnia ok. 240 osób w przeliczeniu na pełne etaty. Drugim z badanych podmiotów (,Y”) jest szpital publiczny, dla którego organem założycielskim i nadzorującym jest jednostka samorządu terytorialnego. Średnioroczne zatrudnienie w tym szpitalu w przeliczeniu na pełne etaty to 335 osób.

Na koniec 2015 roku wynik finansowy przedsiębiorstwa „X” wynosił ok. 1,5 mln euro, natomiast dla organizacji „,Y ok. 121 tys. euro. Na koniec 2019 roku badane podmioty wykazywały zysk w wysokości: ok. $2 \mathrm{mln}$ euro (przedsiębiorstwo for-profit) i ok. 0,5 mln euro organizacja non-profit.

Wykorzystując informacje zawarte w bilansie oraz rachunku zysków i strat ryzyko finansowe dla badanych szpitali określono w oparciu o wskaźniki płynności finansowej i wskaźniki zadłużenia.

Tabela 2.

Wskaźniki płynności finansowej

\begin{tabular}{|l|l|l|l|l|}
\hline Przedsiebiorstwo & 2016 & 2017 & 2018 & 2019 \\
\hline For-profit „X” & 1,37 & 1,27 & 2,04 & 3,08 \\
\hline Non-profit „Y” & 0,21 & 0,95 & 0,50 & 0,27 \\
\hline
\end{tabular}

Źródło: obliczenia własne $w$ oparciu o udostępnione dokumenty

Wskaźnik ten informuje o zdolności organizacji do terminowego regulowania zobowiązań krótkoterminowych z aktywów bieżących. Wartość tego wskaźnika wynosząca w przedsiębiorstwie „X” powyżej 1,2 przy zalecanej wielkości $1,2-2,0^{15}$ wskazuje na systematyczną poprawę płynności finansowej. W przedsiębiorstwie „Y” wartość tego wskaźnika kształtuje się na poziomie dużo niższym od wielkości uznawanej za dopuszczalną. Wskazuje to na brak zdolności tego przedsiębiorstwa do regulowania zobowiązań bieżących oraz

\footnotetext{
${ }^{15}$ M. Sierpińska, T. Jachna, Metody podejmowania decyzji finansowych, PWN 2007, s. 81

(C) Lewandowska Hanna, Olga Vikarczuk
} 
wzrastającą skłonność do powiększania zadłużenia. Potwierdzeniem tego wniosku jest wskaźnik zadłużenia ogólnego, informujący w jakim stopniu majątek badanych organizacji finansowany jest kapitałami obcymi.

Tabela 2.

Wskaźnik zadłużenia (\%)

\begin{tabular}{|l|l|l|l|l|}
\hline Przedsiebiorstwo & 2016 & 2017 & 2018 & 2019 \\
\hline For - profit „X” & 25,0 & 23,9 & 19,8 & 15,45 \\
\hline Non - profit „Y” 136,1 & 120,0 & 135.9 & 168.9 \\
\hline
\end{tabular}

W przedsiębiorstwie „X” wartość wskaźnika oscylująca w granicach od 25\% w 2016 roku do ok. 15\% w 2019 roku wskazuje na postępujący proces zmniejszania się poziomu zadłużenia (ryzyka niewypłacalności). Zupełnie inna sytuacja występuje w organizacji non-profit „Y”. Wysoka i rosnąca wartość tego wskaźnika świadczy o całkowitej zapaści finansowej (zalecana wysokość wskaźnika powinna wynosić od ok. 57\% do ok. 67\%).

Monitoring ryzyka finansowego wskazuje, że w przedsiębiorstwie „X” ryzyko uległo zmniejszeniu, natomiast $\mathrm{w}$ organizacji „Y” ryzyko związane $\mathrm{z}$ działalnością zwiększyło się. Zwiększenie tego ryzyka w podmiocie non-profit związane jest z uwarunkowaniami zewnętrznymi, do których należą m.in. uregulowania prawne państwa związane m.in. ze wzrostem wynagrodzeń. Są to również rosnące koszty utrzymania obiektu związane ze wzrostem kosztów opłat za media (woda, ścieki, ogrzewanie, wywóz śmieci, itd.). W przypadku przedsiębiorstwa for-profit każdy wzrost tych kosztów proporcjonalnie zwiększa cenę produktu/usługi.

Aktywność badanych przedsiębiorstw w wykorzystaniu zasobów charakteryzują wskaźniki gospodarowania tymi zasobami - zwłaszcza zasobami ludzkimi. Wskaźnik ten jako charakteryzujący produktywność tj. wydajność pracy przypadającą na jednego zatrudnionego jest wskaźnikiem uniwersalnym pozwalającym na porównanie ze sobą przedsiębiorstwa for-profit i non-profit. 
Uwzględnienie przychodów ze sprzedaży pozwala poprawnie odczytać efektywność działalności badanych podmiotów.

Tabela 4.

Wydajność pracy

\begin{tabular}{|l|l|l|l|l|}
\hline Przedsiebiorstwo & 2016 & 2017 & 2018 & 2019 \\
\hline For - profit „X” 2,04 & 2,47 & 3,27 & 3,87 \\
\hline Non - profit „Y” & 0,75 & 0,51 & 1,13 & 2,36 \\
\hline
\end{tabular}

Wartość sprzedaży przypadająca na jednego pracownika jest znacznie wyższa w prywatnej klinice niż w szpitalu publicznym. Wartość ta zależy nie tylko od wysiłku pracownika wyrażonego ilością produkcji/świadczenia usług, ale również od ich jakości, wysokości cen i rozwiązań organizacyjnych. Są to więc czynniki niezależne od pracownika.

Zupełnie inaczej należy interpretować wskaźniki związane $\mathrm{z}$ wykorzystaniem środków trwałych (produktywnością) w podmiotach ochrony zdrowia. Ze względu na wysoką wartość wyposażenia w specjalistyczną aparaturę i sprzęt niezbędny do świadczenia usług, wskaźnik ten wraz ze wzrostem wartości środków trwałych wykazuje tendencję malejącą.

Tabela 5.

Produktywność środków trwałych

\begin{tabular}{|l|l|l|l|l|}
\hline Przedsiebi & 2016 & 2017 & 2018 & 2019 \\
\hline For - & 3,4 & 3,3 & 3,1 & 3,1 \\
\hline Non - & 2,1 & 2,3 & 2,1 & 2,3 \\
\hline
\end{tabular}

Produktywność środków trwałych pokazuje, ile razy przychody ze sprzedaży świadczonych usług są wyższe od środków zaangażowanych w ich generowanie. W szpitalu klinicznym „X” przychody te są ok. 3 razy wyższe od uzyskanego przychodu. Ze względu jednak na ciągłe doposażanie podmiotu w nowoczesny sprzęt i aparaturę, wykazują one stabilny poziom wynoszący ok. 3 zł przypadający na każdy 1 zł zaangażowany w środkach trwałych. W szpitalu (C) Lewandowska Hanna, Olga Vikarczuk 
„Y” wskaźnik ten kształtuje się na poziomie ok. 2,3 zł na każdy 1 zł środków trwałych, co świadczy o braku inwestycji w restytucję posiadanych środków trwałych. Przedstawione podejście wskazuje na politykę zarządzania przyjętą przez badane podmioty. W klinice „X” postawiono na inwestycje, aby w latach przyszłych osiągnąć większe przychody i zdobywać nowych klientów, natomiast $\mathrm{w}$ podmiocie „Y” prowadzona jest zachowawcza polityka zarządzania. Oceniając badane podmioty należy jednak pod uwagę wziąć uwarunkowania prawne (podmiot prywatny for-profit „X” i podmiot publiczny non-profit „,Y”, w oparciu o które prowadzą swoją działalność.

Podsumowanie. Ryzyko jako zjawisko niejednorodne dotyczy wszystkich dziedzin funkcjonowania organizacji czyli jej finansowania, procesu świadczenia usług, zarządzania zasobami ludzkimi, itp. Ryzyko finansowe w organizacji stanowi wypadkową wszystkich decyzji i działań podejmowanych przez zarządzających. Najczęściej są to błędne założenia dotyczące wykorzystania zasobów organizacji przy planowaniu usług. Zmienność otoczenia i jego oddziaływanie na organizacje wymaga jednak, aby w celu zapewnienia sobie dalszego rozwoju i przetrwania organizacje zwracały uwagę na źródła i przyczyny powstawania ryzyka. Wczesne wykrywanie i zidentyfikowanie zagrożeń pozwala na ich zmniejszenie. Istotną rolę odgrywa także nadzór właścicielski. W badanym szpitalu „X” udziałowiec szpitala aktywnie uczestniczy we wszystkich przedsięwzięciach dotyczących funkcjonowania organizacji dążąc do uzyskania celu i określonych wyników (finansowych). W szpitalu publicznym ,Y” zakres uczestnictwa organu nadzorującego sprowadza się natomiast do biernej obserwacji działalności i braku działań zmierzających do poprawy funkcjonowania szpitala. W organizacji „X” na bieżąco monitorowane jest otoczenie zewnętrzne oraz przeprowadzana jest analiza odchyleń w poszczególnych oddziałach, natomiast w organizacji „Y” takie działania nie są prowadzone. Celem strategicznym szpitala „X” jest ekspansja na rynku usług medycznych, natomiast szpital „Y” 
ze względu na swoją rolę (zabezpieczenie podstawowych usług zdrowotnych) prowadzi działalność restytucyjną (odtworzeniową). Sformułowane wnioski pozwalają na pozytywne zweryfikowanie przyjętej hipotezy o możliwości wystąpienia wyższego ryzyka w każdym obszarze funkcjonowania w szpitalu publicznym „Y” niż w klinice prywatnej „X”- podmiocie prawa handlowego.

\section{REFERENCES}

1. Basseler, U., Heinrich, J., Koch, W. (1991). Grundlagen und Probleme der Volkswirtschaft [Fundamentals and problems of the economy]. Wirtschaftsverlag Bachem, 344.

2. Griffin, R.W. (2005). Podstawy zarządzania organizacjami [Fundamentals of organization management]. PWN Warsaw, 311.

3. Kaczmarek, T.T. (2010). Zarządzanie ryzykiem [Risk management]. Difin, 132.

4. Kendall, R. (1988). Zarządzanie ryzykiem dla menedżerów [Risk mangement for the managers]. Liber Warsaw, 15.

5. Knight, F.H. (1985). Risk. Uncertainty and Profit. Chicago-London, 233.

6. Kotler, P., Caslione, J. (2009). Chaos. Zarzadzanie i marketing w erze turbulencji [Chaos. Management and marketing in the era of turbulence]. MTBiznes, 21.

7. Kotler, P., Caslione, J. (2009). Chaos. Zarzadzanie i marketing w erze turbulencji [Chaos. Management and marketing in the era of turbulence]. MTBiznes, 29.

8. Ronka-Chmielowiec, W. (2010). Wykorzystanie ubezpieczeń do zarządzania ryzykiem $\mathrm{w}$ przedsiębiorstwie [The use of insurance to manage risk in the enterprise]. [w:] Zarządzanie ryzykiem działalności organizacji [Organization risk management]. C.H. Beck Warsaw 2010, 52.

9. Marks, S.G., Samuelson W.F. (1998). Ekonomia menedżerska [Managerial economics]. PWE, 40. 
10. Rowe, W.A. (1977). Risk is potential for realization of unwanted, negative consequences of an event [w:] An Anatomy of Risk. New York, 24.

11. Sierpińska, M., Jachna, T. (2007). Metody podejmowania decyzji finansowych [Methods of making financial decisions]. PWN, 81.

12. Willet, A.H. (1951). The Economic Theory of Risk insurance. Philadelphia, 6.

13. Glosariusz Międzynarodowych Standardów Profesjonalnej Praktyki Audytu [Glossary of International Standards for Professional Auditing Practice]. The Institute of Internal Auditors (2001), Altamonte Springs, Florida.

14. Zarządzanie ryzykiem w sektorze publicznym [Risk management in the public sector]. Ministry of Finance Warsaw. Project UE Transition Facility 2004/016- 829.01.0.

Статтс надійшла до редакиії 4.03.2020 